Jusmal lemiah
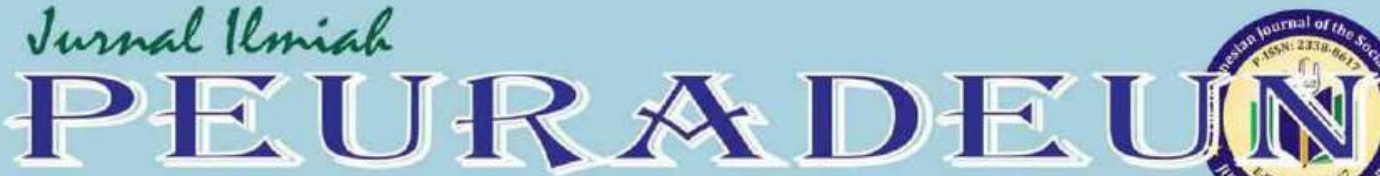

Vol. 6, No. 1, January 2018

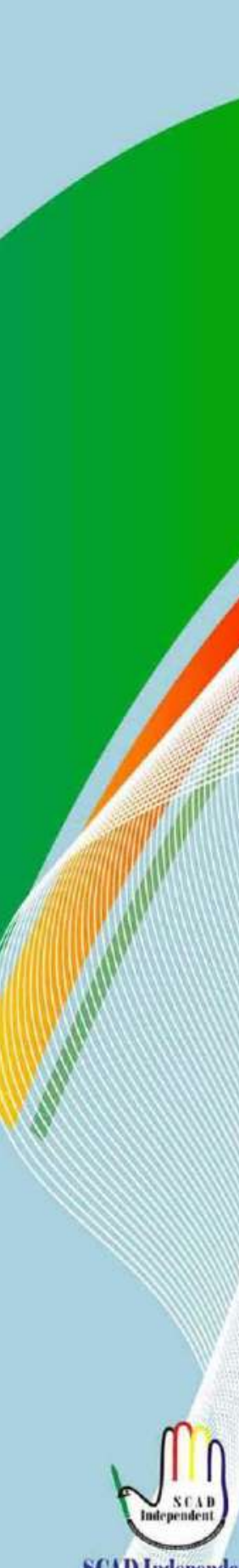

SCAI) Independent Accreditatioa by HO since 2014 $\bigodot$ Copernicus Publications

\section{III}

The Indonesian Journal of the Social Sciences www.journal.scadindependent.org Dot Prefix Number: 10.26811

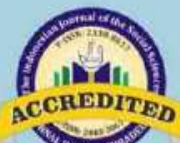

ACCREDITED - B" by the Ministry of Risteklikti from Oetaber 30, 2017 until Oetober 30, 2022

\section{Clarivate Analytics}

Emerging Sources Citation Index Web of Science ${ }^{\mathrm{TM}}$

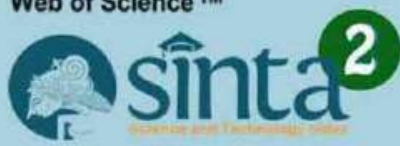
INDEX $\circledast$ COPERNICUS 


\title{
THE APPLICATION OF UNITY-ORIENTED PERSUASIVE COMMUNICATION OF PROPHET MUHAMMAD IN THE PLURAL SOCIETY OF MEDINA CITY
}

\author{
M. Nasor \\ Raden Intan State Islamic University of Lampung, Indonesia \\ ContibutorEmail: nasor@radenintan.ac.id
}

\begin{abstract}
Plural society built by the prophet was a reflection of an ideal society that can live together as the result of the application of a persuasive communication. A plural society is a society that is composed of various groups, races, tribes, nations, and others. Their existence should get a proper guidance so that people could possess certain qualities such as loving the good deeds and against the bad deeds and violence as Islam instructs. Universal Islamic values govern relations based on mutual respect, non-coercion, justice, humanity, togetherness, and brotherhood. Islam as a social religion strongly supports the effort to establish the relationship of human dignity as a whole. For that, it seems necessary to have a persuasive communication that can touch the psychological aspects of various societies. This method will be easier to bring about an effective result that is the commitment of each group on faith and humanity with the boundaries of rights and obligations. Such situation can foster motivation and confidence to achieve unity and the welfare of the people, which in turn they can live in tolerance, justice, togetherness, brotherhood, and many others.
\end{abstract}

Keywords: Persuasive Communication, Plural Society, Unity, Medina City 


\section{A. Introduction}

The state of the people of Medina was a plural society consisting of various cultures, religions, ethnics, and tribes that inhabits one single place. Maulavi Muhammad Ali (1950: 121) states that Medina society was a society consisting of Muslims and Jews and others as a nation that lived together and mingle with others. Further, Zainal (1973: 93) says their diversity consisted of sex, tribe, race, and nation. The Medina community consisted of the Muhajirin people, the Ansar people, the Hypocrites, the pagan tribes, and the Jews.

In the beginning, they had mutual quarrels and disputes, but the persuasive acts of the Prophet were able to lead them into a peaceful life. The human background varies due to the different ideological set which has a very binding role to his opinion, according to the explanation of Surah Yunus verse 19 (QS 10:19)And mankind was not but one community [united in religion], but [then] they differed. And if not for a word that preceded from your Lord, it would have been judged between them [immediately] concerning that over which they differ.

The Qur'anic verse above as Abdullah (1992: 12) claims that at the beginning, human is united in one religion, then they split into several groups as a result of disunity caused by disobedience. The reality of human life in this world is depicted as there is a group of obedient people and there is also a group of people who disobey the teaching of Islam. Plural society is a conflict-prone society in nature when left without guidance to a harmonious life. This condition is the duty of the preachers to foster a better and more conducive way of life. Prophet Muhammad PBUH after performing hijra to Medina has done a lot of coaching that focuses on development on various elements of life. Sayyid Mahmud (1994: 119) depicts the action of Prophet Muhammad PBUH in fostering the community and bringing positive aspects to the order of social life, so that he is known as a reformer for the system of true social order.

His success was inseparable from his expertise in applying persuasive communication, building a more advanced society in a unified frame. It would certainly lead them to a high level of solidarity and loyalty to strive for the truth. Such personality is indispensable to the welfare of society in the setting of unity. That condition is a civilized society, which is a society that can reside together in harmony. (Yusuf Qardhawi, 1977: 243). On the other side, according to Ahmad, 
civilized society is a society that is submissive and obedient to the doctrine of obedience stated in the supremacy of law and regulation. (Ahmad Baso, 199: 21).

The principle of the goal in fostering a plural society is characterized by loving the kindness and opposing violence. The success is certainly as the result of Prophet Muhammad's PBUH contribution of who put forward persuasive communication. Arnold (1985: 4) explains that the policies developed by Prophet Muhammad PBUH in fostering the plural society by means of persuasive communication are gentle in nature.

\section{B. Formulation of Problem}

As explained earlier that the application of persuasive communication applied by Prophet Muhammad PBUH has been able to foster the diversity of community life in the basis of brotherhood. The existence of this strong and effective network to create a unified society in carrying out development is deemed necessary. The formulation of the problem of this study is "How is the application of persuasive communication of Prophet Muhammad PBUH on plural society in the frame of unity at the city of Medina?"

\section{Research Methodology}

This is a literature research. It means that this research is conducted by reading and studying books quoted from various theories and opinions that correlate with the problems studied. This authors examined, reviewed various information and data associated with persuasive communication in Islam that is used to foster a plural living society.

The sources of data in this study are primary and secondary data sources. Primary data sources was taken from books related to persuasive communication of Islam in fostering plural society, they are: Sirah Nabawiyah by Ibn Hisham, Tarikh al-Islam by Hasan Ibrahim Hasan, alBidayah wa al-Nihayah and al-Sirah al-Nabawiyyah by Ibnu Kasir, Muqaddimah and Tarekh by Ibnu Khaldun, Alfadz wa al-A'lam alQur'aniyyah by Muhammad Ismail Ibrahim, al-Sunnah Mashdaran li alMa'rifah wa al-Hadharah by Yusuf Qardhawi, Classical Islam by G.E. Von 
Grunebaum, The Preaching of Islam by Thomas W. Arnold, Social Contract and Islamic State by Muhammad Isya Ayash, , and The Eternal Message of Muhammad by Abd. Al-Rahman Azzam.

Sources of secondary data were based on other literature related to persuasive communication of Islam in fostering plural society, namely: Daulat al-Rasul fi al-Madinah by Ahmad Ibrahim Syarif, Persuasion, Reception, and Responsibility by Charles U. Larson, Speaking Persuasively by Joseph R. Berger and Steven H. Chafee, Handbook of Communication Science by Charles R. Berger and Steven H. Chafee, Ummah or Nation ?, Identity Crisis in Contemporary Muslim Society by Abdullah al-Ahsan, Intercultural Communication: A Guide to Communicating with Different People and Culture by Dedy Mulyana.

To analyze the data of literature through historical approach is to learn past events related to persuasive communication of Islam in fostering plural society. The writer also used discourse analysis which is a research approach to see the development of discourse that includes utterances and all kinds of texts in a broad sense.

\section{Frame of Thinking}

\section{Persuasive Communication}

Human interacting with others to convey certain points of or ideas requires communication skills. Someone communicates can be just to convey information, but sometimes want to influence the attitude and behavior of listeners. To achieve the desired outcomes or goals, it is necessary to communicate persuasively, that is a type of communication that can touch and convince psychological aspects of others. Josep Ilardo (1981: 4) argues that persuasive communication is the delivery of messages or points of thought to others in order to change beliefs, attitudes, and behaviors through psychological aspects. Another expert, Larson (1986: 7) describes persuasive communication as a conscious effort in order to identify thoughts and actions based on human motives into predetermined goals.

Persuasive communication consists of several components, as in other communications, namely: communicators, messages, communicants, media, 
and situations. (Onong Uchyana Effendy, 1986: 106). A communicator is a person who conveys information to others. Messages are materials that will be presented to listeners. Communicant is the person receiving the message. Media is a tool for sending messages. The media are electronic and printed, such as: television, radio, telephone, internet, telegram, newspapers, magazines, leaflets, banners, and many others. Situation is a state, atmosphere that is physical, psychological, social, and temporal. (Alo Lili Weri, 1994: 55-56). Based on the mentioned various components, the delivered messages are not specified / focused by only one element, but will be related to other elements. The mutual involvement of the elements will complement each other in the process of persuading a person.

\section{Plural Society}

Life with others is a plural reality of life consisting of different religions, tribes, customs, genders, and so on. It should be the plural life that is the basis for unity and not to divide one another. Pluralism or cultural diversity such as tribe, race, nation, and gender must provide goodness and peace and not to bring about mischief or misery. The unification of all these elements will form a certain system that plural life becomes increasingly important. The word plurality or pluralist generally interpreted as jama 'or more than one. Plural life is a sociological reality that is a plural in existence indicated by the existence of more than one belief or sect. Likewise, Frithjof (1993: 76) says that the pluralism is derived from the word pluralist which means more than one, or pluralizing which means equal to the number that shows more than one, or more than two (dualism), while pluralism is equal to the circumstances or beliefs in a plural society concerned with its social and political system as a distinct cultures in one society.

\section{The Urgency of Persuasive Communication in the Development of Plural Society}

Communication as one of the activities on the development of plural society is considered very important in human life. In line with 
that, Andi (2017: 3-4) argues that communication plays a very important role in human life. By communication, the nature of human beings as social beings can be fulfilled. Two people are said to be interacting, when each takes action and reaction. These actions and reactions done by humans are referred to as communication actions.

One's success in community development can reach its peak when planning and communication can be effectively implemented. According to Arvin Kumar (2000: 121-122) communication can be effective when the message conveyed also affects and touches the psychological aspects of a person with the characteristics of: openness, empathy, supportiveness, positive attitude, and equality.

\section{E. The Results of the Research and Discussion.}

Persuasive communication applied by Prophet Muhammad PBUH to the plural society can be seen below:

1. Society's Tolerance on Diversity.

Prophet Muhammad PBUH in fostering the community did not recognize the separation between the diversity of human life, to appreciate the diversity of beliefs, customs, and others and not to wage war among them. The guidance also commands the relationships to bring about unity, peace, and mutual respect, until a sense of tolerance arises. In the Qur'an (Al-Maidah: 2) it is affirmed that human uphold the tolerance between the people:

It means "O you who have believed, do not violate the rites of Allah or [the sanctity of] the sacred month or [neglect the marking of] the sacrificial animals and garlanding [them] or [violate the safety of] those coming to the Sacred House seeking bounty from their Lord and [His] approval. But when you come out of ihram, then [you may] hunt. And do not let the hatred of a people for having obstructed you from al-Masjid al-Haram lead you to transgress. And 
cooperate in righteousness and piety, but do not cooperate in sin and aggression. And fear Allah; indeed, Allah is severe in penalty."

Tolerance works if calls and invitations for peaceful living in the diversity or diversity of life in peace. The existence of togetherness requires tolerance that prioritizes the spirit of peace. The attitude of tolerance in pluralism is to acknowledge the existence of uniformity in our midst as a reality and impossible to avoid in life. Tolerance can be realized, Alwi Shihab states that in life we are not merely showing the fact that there is diversity, but there must be an active involvement toward the pluralism. The tolerance in religion that every believer required is open to recognize the existence and rights of other religions, but also to engage in the understanding of differences and equality in order to achieve harmony in diversity. (Alwi Shihab, 1988: 41). Also, Mursyid Ali (2000: 39) assumes that tolerance in plurality can be accomplished by three things: First, the acceptance of the presence of other groups based on the concept of peaceful coexistence, which does not interfere with each other. Second, the attitude of developing social cooperation through various activities that are symbolic and functional that encourage the process of harmonious life development. Third, seek, develop and formulate points or solutions in order to answer the problems, challenges, and concerns of mankind.

A tolerant life should not be interpreted as an acknowledgement that all religions are true, nor are they meant to worship other religions. But on the other aspects of moral values, such as honesty, togetherness, helping each other, and more, we must be willing to do wherever and whenever in life. Tolerance Understanding emphasizes the religious community to be obedient, submissive to God and obliged to establish a good communication with others.

In the life of tolerance, besides firmly clinging to one's beliefs, is it not forbidden to engage in human relationships. Relationships are not merely limited to religious matters, since the interaction on the issues of social life that do not distinguish between sex, ethnicity, religion, custom, nations and others are allowed. Prophet Muhammad PHUH fostered the society of Medina consisting of various groups, namely: Islamic society, 
Musyrikin (paganism), Jewish community, and the Christian community. (G.E. Von Grunebaum, 1970: 26). In addition, in the Medina community there also existed several factions, namely: the Muslims consisting of the Jews and the Ansar, the Auws and Khazzraj who converted to Islam which were still in the beginner level of converted (there were still some who hated Muslim), the people of Auws and Khazzraj who still adhered to the beliefs of paganism that in short time converted to Islam, the Jews of Banu Nadzir, Banu Qoinuqa, and Banu Quraidhah. (Muhammad Zafrullah Khan, 1980: 88).

The Document of Medina Charter governs the issue of tolerance begins with the sentence in the name of God, the most merciful and the most beneficent. Muhammad as the messenger of God with the followers of Quraish and the Yastrib in Medina, as well as those who followed him, they joined themselves and fought with them. (Muhammad Isya Ayash, 1964: 173). The existence of Medina's diversity does not deny other religions and does not force people to convert. Through the 25th chapter of the Medina Charter it had been established that the Jews stick to their religion and the believers remain in their religion. Chapters 15 and 16 emphasize the importance of cooperation between different groups. Fathur Rahman (1984: 13) explains that through the articles in the Medina Charter, freedom of religion for the Jews and others had been guaranteed in order to realize mutual cooperation with the Muslims.

Guidance that acknowledges diversity guarantees the people to keep their beliefs and practice their teachings. Indeed, a diverse society will preserve its diversity that can bring about religious harmony and implement tolerance. Although they live in potentially diverse society, but they give the opportunity for mutual respect and awareness of where they are. Life like this is interesting, beautiful and comfortable, there is no strife or permanent conflict in togetherness that gives great opportunity to realize unity. The pluralism in the history of Prophet Muhammad PBUH fostered the harmony of a plural society that could bring about the unity of the Muslim community and the Yathribs in a strong foundation of freedom and communion. (Muhammad Husein Haikal, 1990: 198). 


\section{Just Society}

A diverse life can work well and manifest when people behave fairly. The dimension of justice is a prerequisite for a community development in establishing the foundation of order that covers the whole society components. Fair and justice hold an important value to strengthen the bond and to eradicate the ethnicity fanatics among groups. Justice is a fair act in the people's rights and obligations. A well developed society in a nation could be achieved when it is supported by the principles of justice. As an example; the role of the governments that applied the principle of justice, do not oppress the people, do not abuse the power, and always take care of the people's need, it means that the governments have already succeeded in guiding its citizen.

The nature of guidance that holds the principles of justice is the one that Prophet Muhammad applied to the people of Medina. Upholding the values of justice means the laws have been set and all legal decisions decided through the court of law. To be just and to establish good relationship among groups indicated one's closeness to God, as Surah Almaidah: 8 says:

(5:8) O you who have believed, be persistently standing firm for Allah, witnesses in justice, and do not let the hatred of a people prevent you from being just. Be just; that is nearer to righteousness. And fear Allah; indeed, Allah is Acquainted with what you do.

The mission of Prophet Muhammad PBUH in imposing the values of justice in the Charter of Medina chapter 2 stated that the believers must be fair in paying riyat and redeem the prisoner so that no party is harmed. Article 13 states the believers are fair to the perpetrators of evil, injustice, and sin. Article 17; non-Muslim groups, Jews and their allies receive protection and equality as Muslims do. (M. Nasor, 2011: 233).

Obtaining justice is a fundamental right of every human being, Muslim or non-Muslim, in order to obtain protection. Justice must be upheld, because it has become the main aspect that demands its citizens to do justice in life together. Upholding justice means holding, upholding, and performing duties well to fulfill the rights of others. 
3. Society in the Unity of Ummah

The dimension of the unity of ummah according to Ismail Ibrahim (1969: 46) implies that the word ummah means as all groups are gathered under certain conditions, such as religion, the same place or time, based on external factors or their own will. An expert named Abdullah says that: the word ummah is used in the sense of a bond of religious fellowship that appeared before Prophet Muhammad SAW. (Abdullah Hasan, 1992: 11). The unity of the ummah is a prerequisite for the life in plural societies to strengthen the true bond in unity and eliminate tribal fanaticism among groups. This is in accordance with the thought of Ibrahim Sharif (1972: 99) that: the unity of a congregational community that is religion and belief as a binder of the unity of the ummah.

Medina Charter contains some agreed-upon provisions for arranging social life in Medina. The Medina Charter is a unique document, the first modern-day constitution born in pre-modern times, to organize a society capable of great change. Ibn Khaldun (1979: 127) in his book explains that: the original Arabs who were rude, arrogant, hostile with other tribes, and hard others, along with religious bonds their character began to change, rough and arrogance to be gentle and obedience.

The people of Medina that could be united is the result of the Prophet Muhammad's (PBUH) success in fostering society in togetherness. With the unity, the community was able to live in a plural, tolerant, egalitarian, equitable, and others. The success of the Prophet in unifying the people of Medina in the unity of the ummah, to the point of influencing their attitude, can be said that the Prophet has succeeded in communicating persuasively. Upholding the unity has become the main joint in upholding and fulfilling the mandate well to meet common needs. Prophet Muhammad PBUH guided through the aspects of life provided an opportunity in various activities to the existing groups to interact through psychologically-bonded and mutual needs communication. The way of the communication according to Mulyana (1996: 31) was persuasive communication that could touch the psychological aspects of multicultural society in order to establish a relationship and is a win-win 
solution not win-lose, means our partners are not harmed and mutually equal before justice.

\section{Togetherness community}

Living with others when there is good treatments to the people concerning all things. Togetherness is the nature of human beings as social beings who interact, communicate, exchange thoughts, and remind each other. The text of the Mitsaq al-Madinah covenant or Medina Charter as was the first foundation to carry out the guidance of the plural society in the life of togetherness. The Charter consists of several chapters and articles that possessed important value to regulate the rights and obligations of the community in living together situation. Ibn Kathir (1978: 224) explains that the Medina Charter is a document written as a basis for arranging a covenant between the Muhajirins, Ansars and Jews, recognizing freedom of religion, guaranteeing their property, and guaranteeing their rights and obligations in living together. According to Ibrahim Hasan (1979: 103) that the interests of Muslims and non-Muslims in Medina Charter were addressed to ensure the rights and obligations of all groups on the issues that were acceptable to all parties with pleasure.

The principle of togetherness will essentially erode mental diseases such as resentment, jealousy, envy, stubbornness, arrogance, and others. Therefore, society will be stronger based on high solidarity and more manageable for the success of development. In accordance with the phrase, Ibn Khaldun (t.th.: 151-152) states that the Prophet Muhammad PBUH had laid the foundations of togetherness so that people could easily get what they want. Through togetherness people can conquer their lusts, curb their arrogance, erase their envy, eliminate vengeful resentment, and more easily to be lead into unite.

The success of Prophet Muhammad PBUH in fostering plural society in the name of togetherness was a strategic step in communication that put forward persuasiveness. Alexander (1969: 9) explains that communication is a process in which a person conveys stimulation to others to create togetherness for two or more people that were originally monopolized by one or several people. 
5. Society in Brotherhood

Brotherhood in the life of plural society is the principle of solidarity that does not differentiate the groups in order to eliminate the conflict to realize the welfare of society. They live in harmony, peace, helpful, and protective to each other on various occasions. Abd. AlRahman 'Azzam (1979: 65) describes the Prophet Muhammad's (PBUH) invites all mankind to believe and worship God, form a nation, promote brotherhood that did not distinguish between tribes, races, nations and others which includes all components or layers of society to participate in defending the city Medina. The brotherhood fosters an atmosphere of solidarity, upholds common responsibilities, and encourages progress. In line with the opinion of Ibn Hisham (1965: 150) that in the Medina period, the prophet had laid the foundations of a solid brotherhood, such as Muhajirin and Ansar unification that were different tribes and customs, as well as other differences. Brotherhood has been built through the mosque as the media, according to Sharif; besides functioning as the place of worshipping practices, the mosque also functioning as the places to strengthen the bonds between Muslims (Ibrahim Syarif, 1972: 87) Establishing brotherhood keeps the overall interest in the field of security, comfort, and cooperation. Practice of the Prophet in realizing brotherhood through cooperation and deliberation on social issues in Medina, Ibn Kathir (1978: 370) says that: The Prophet often displayed the attitude of listening to majority opinion, such as the events of the war of Uhud, Badar, Hudaibiyah, up to the personal problems and household problems.

Strengthening brotherhood in a plural society is a strategic step to foster society to defend the truth, which can eliminate all bonds such as: ethnicity, nationality, customs, ancestry, and others. The strong bond of the brotherhood will encourage the willingness to sacrifice, to motivate, and to strive to create an independent society. Even more than that, people are caring about togetherness; acting on the basis of current and future interests and making common goals come true.

Regarding the brotherhood built by Prophet Muhammad PBUH as mentioned before, the steps are based on the principles of persuasive 
communication. Brotherhood is a trait that can cultivate a sense of affection and cause a sense of closeness among each other. With the said closeness, Prophet Muhammad PBUH influenced the behavior of society easily and successfully. Charles R. Berger (1987: 464) says a persuader who has close relationship with the audience has the ability to make changes so that the communicants feel that the communicator is more satisfying in conveying his message.

\section{F. The Results of the Research and Discussion}

A plural society reflects the social order that accepts and respects differences. The existence of such society was the result of the approach of the Prophet in applying persuasive communication, resulting in loving and respecting each other, accepting diversity, and building harmony in togetherness. That kind of conditions in the end can accommodate tolerance, togetherness, and unity, so that awareness could emerge in order to build a more advance society. Such society is a societal order that put forward equality, freedom, justice, and cooperation to achieve prosperity. The success in fostering communities of diverse ethnics, races, and often conflict-ridden groups to be united; is a form of guidance that put forward an egalitarian life paradigm free from discrimination.

\section{Bibliography}

Ahmad, Zainal Abidin. (1973). Piagam Nabi Muhammad SAW Konstitusi Tertulis Pertama di Dunia, Jakarta: Bulan Bintang.

Al-Ahsan, Abdullah. (1992). Ummah or Nation?, Identity Crisis in Contemporary Muslim Society, The Islamic Fondation.

Ali, Mursyid. (2000). Problem Komunikasi Antar Ummat Beragama, Jakarta: Balitbang. Al-Nasir, Sayyid Mahmud. (1994). Islam Konsepsi dan Sejarahnya, Bandung: PT. Remaja Karya Rosda Karya.

Al-Rahman, Abd. (1979). “Azzam, The Eternal Message of Muhammad, London-Melbourne-New York: Quarted Books.

Arnold, T.W. (1985). The Preaching of Islam, terjemahan Nawawu Rambe, Sejarah Dakwah Islam, Jakarta: Wijaya. 
Ayash, Muhammad Isya. (1964). Social Contrac and Islamic State, New York: Oxford University.

Baso, Ahmad, (1999). Civil Society Versus Masyarakat Madani, Bandung: Pustaka Hidayah.

Berger, C.R. \& Steven H. Chafee. (1987). Hand Book of Communication Science, New Delhi: The Publisher of Professional Social Science, New Barry Park Baverly Hill.

Buseri, K. (2015). Epistemologi Islam dan Reformasi Wawasan Pendidikan. Jurnal Ilmiah Peuradeun, 3(1), 77-102.

Charles U. Larson. (1986). Persuasion, Reception, and Responsibility, USA: Wadsworth Publishing Company.

Departemen Agama/Depag. RI. (1971). Al-Qura'an dan Terjemahnya, Jakarta: Yayasan Penterjemah/Penafsir Al-Qur'an.

Effendy, Onong Uchyana. (1986). Hubungan Masyarakat Suatu Studi Komunilogis, Bandung: Remaja Karya.

Faruqi, Y. M. (2015). Role of Muslim Intellectuals in the Development of Scientific Thought. Jurnal Ilmiah Peuradeun, 3(3), 451-466.

Grunebaum, G.E.V. (1970). Classical Islam, terj. Katherin Watson, Chicago: Aldine Publishing Company.

Hasan, Ibrahim. (1979), Tarekh al-Islam, Kairo: Maktabat al-Nahdlat alMisriyat, Jilid I.

Hermawan, S. (2014). Hukum Islam dan Transformasi Sosial Masyarakat Jahiliyyah. Jurnal Ilmiah Peuradeun, 2(3), 81-96.

Hisyam, Ibnu. (1965). Sirah Nabawiyah, Kairo: Mustafa al-Baby al-Halaby, Jilid II.

Ibnu Katsir, al-Imam Abu Fida' Ismail. (1978). al-Bidayah wa al-Nihayah, Bairut: Dar al-Fikr, Jilid III.

Ibrahim, Muhammad Ismail. (1969). Alfadz wa al-A'lam al-Qur'aniyyah, Kairo: Dar al-Fikr Arabi.

Illardo, A.J. (1981), Speaking Persuasively, Mc. Millan.

Ismail, M. (2015). The Effectiveness of Agreement Hudaybiya. Jurnal Ilmiah Peuradeun, 3(2), 295-310. 
Karibi, R. A. I. N. (2015). Religion, Human Rights and the Challenges of Freedom. Jurnal Ilmiah Peuradeun, 3(1), 39-54.

Khaldun, Ibnu. (1979). Tarekh Ibnu Khaldun, Libanon: Dar al-Fikr, Jilid I.

Khaldun, Ibnu. (t.th). Muqaddimah, Bairut: Dar al-Fikr.

Khan, M.N. (1980). Muhammad Seal of the Prophet, Lahore: Routledge and Kegan Paul, 1980.

Kumar, Arvin (ed.) (2000). Encyclopedia of Mass Media and Communication, (New Delhi: Anmol Publication Pvt. Ltd., 2000.

Lvina, E. (2015). The Role of Cross-Cultural Communication Competence: Effective Transformational Leadership Across Cultures. Jurnal Ilmiah Peuradeun, 3(1), 1-18.

Meraj, M. A. (2016). Islamic Approach to The Environment and The Role's in The Environment Protected. Jurnal Ilmiah Peuradeun, 4(1), 1-14.

Muhammad Ali, M. (1950), Muhammad The Prophet, Lahore: Iradahi alAdabiyati, 1950.

Muhammad Husein Haikal, Hayat Muhammad, terj. Ali Audah, Sejarah Hidup Muhammad, Jakarta: Lentera Antar Nusa, 1990.

Mulyana, Dedy. (1996). Komunikasi Antar Budaya: Panduan Berkomunikasi Dengan Orang-Orang Berbeda Budaya, Bandung: Remaja Kerya.

Nasor, M. (2011). Komunikasi Persuasif Nabi Dalamm Pembangunan Masyarakat Madani, Surabaya: Pustaka Emas, 2011.

Nufiar, N., \& Idris, S. (2016). Teacher Competence Test of Islamic Primary Teachers Education in State Islamic Primary Schools (MIN) of Pidie Regency. Jurnal Ilmiah Peuradeun, 4(3), 309-320.

Putra, Andi Eka. (2017). Membangun Komunikasi Sosial Antar Etnik: Perspektif Sosiologi Komunikasi, dalam Jurnal Al-Adyan yang diterbitkan oleh Jurusan Perbandingan Agama Fak. Ushuluddin UIN RIL Lampung, ISSN: 1907-1736, Vol. XII, No.1/JanuariJuni/2017.

Qardhawi, Yusuf. (1977). al-Sunnah Mashdaran li al-Ma'rifah wa alHadharah, Kairo: Dar al-Syuruq.

Rahman, Fathur. (1984). Islam, terj. Ahsin Muhammad, Bandung: Mizan. 
Saifullah. (2015). The Internalization of Democratic Values into Education and Their Relevance to Islamic Education Development (Synthetic, Analytic, and Eclectic Implementation of John Dewey's Thoughts). Advanced Science Letters, 21 (7), pp. 2301- 2304, DOI: $10.1166 /$ asl.2015.6257

Schoun, F. (1993). The Preneal of Fhilosofi Muslim, Bandung: Penerbit Mizan.

Shihab, Alwi. (1988). Islam Inklusif Menuju Sikap Terbuka Dalam Beragama, Jakarta: Kerjasama ANTV-Mizan.

Syarif, Ahmad Ibrahim. (1972). Daulat al-Rasul fi al-Madinah, Kuwait: Dar al-Bayyan.

Tabrani. ZA. (2014). Islamic Studies dalam Pendekatan Multidisipliner (Suatu Kajian Gradual Menuju Paradigma Global). Jurnal Ilmiah Peuradeun, 2(2), 211-234.

Tabrani. ZA. (2014). Isu-Isu Kritis dalam Pendidikan Islam. Jurnal Ilmiah Islam Futura, 13(2), 250-270

Tabrani. ZA. (2016). Perubahan Ideologi Keislaman Turki (Analisis GeoKultur Islam dan Politik Pada Kerajaan Turki Usmani). Jurnal Edukasi: Jurnal Bimbingan Konseling, 2(2), 130-146.

Tan, C. (2015). Educative Tradition and Islamic School in Indonesia. Jurnal Ilmiah Peuradeun, 3(3), 417-430.

Walidin, W., Idris, S \& Tabrani. ZA. (2015). Metodologi Penelitian Kualitatif dan Grounded Theory. Banda Aceh: FTK Ar-Raniry Press

Weri, Alo Lili. (1994). Perspektif Teori Komunikasi Antar Pribadi, Bandung: Penerbit Citra Aditiya Bakti. 